\title{
O descentramento do sujeito nos contos Amor e $O$ crime do professor de Matemática, de Clarice Lispector
}

\section{Decentering of the subject in the short stories: Amor and $O$ crime do professor de matemática by Clarice Lispector}

\author{
Jhony Adelio Skeika*
}

Silvana Oliveira**

\begin{abstract}
Resumo: Recorrente na obra de Clarice Lispector é a questão da tomada de consciência sobre a vida, muitas vezes impulsionada por um momento de epifania, gerando na personagem um sentimento de descentramento e reflexão. Dessa forma, este estudo busca investigar como tal processo é representado nos contos Amor e $O$ crime do professor de Matemática da escritora Clarice Lispector (ambos em: LISPECTOR, 1983). Para esta abordagem, buscou-se subsídio teórico em alguns autores que tematizam questões de identidade, dos quais se pode destacar Stuart Hall e seus estudos sobre o descentramento do sujeito, bem como a problematização sobre a chamada crise de identidade (HALL, 2006, p. 09) e o conceito de exotopia de Mikhail Bakhtin (2003), que apresenta o discurso do outro como crucial para a (re)formulação de toda a identidade, toda consciência e visão de mundo individual.

Palavras-chave: Identidade. Descentramento. Clarice Lispector.

Abstract: The character's consciousness-raising is appellant in Clarice Lispector's work, most of times done by an epiphany moment making inside the character a feeling of identity breaking and reflecting. So, this study looks for investigating how this process is represented in Amor and Ocrime do professor de Matemática, tales written by Clarice Lispector (both published in: LISPECTOR, 1983). For this purpose, some authors that deal with identity questions were researched, which it's pertinent detach Stuart Hall and his studies about the subject decentralizing and identity crisis (HALL, 2006, p. 09) and Mikhail Bakhtin's exotopy conception, which defend the other's discourse is crucial in the (re)making of every identity, conscience and individual world view
\end{abstract}

Keywords: Identity. Decentralizing. Clarice Lispector.

\footnotetext{
*Mestrando. Universidade Estadual de Ponta Grossa - UEPG. E-mail: jhonyskeika@yahoo.com.br

*** Professora doutora. Universidade Estadual de Ponta Grossa - UEPG. E-mail: oliveira_silvana@ hotmail.com
} 


\section{Introdução}

O mais belo estado de vida é a dependência livre e voluntária: e como seria ela possível sem amor? (Goethe, 1992, p. 31)

Juntamente com mais 11 textos do mesmo gênero, os contos Amor e O crime do professor de Matemática encontram-se reunidos no livro Laços de Família ${ }^{1}$, publicado pela primeira vez em 1960. Comum ao universo "clariceano" é o fato de suas personagens serem surpreendidas pela aparição de sentidos insólitos em meio à banalidade de seus cotidianos. É assim que os sujeitos descritos pela autora no livro Laços de Família vão ser problematizados; esta análise está focada no estudo do comportamento de Ana e do Professor de Matemática sob a ótica do descentramento e da tomada de consciência.

No conto Amor, a personagem Ana é uma dona de casa comprometida com o lar e com o bem estar da sua família. Certo dia, voltando de bonde das compras rotineiras ela vê em uma parada um cego mascando chicles. Essa visão a desconcerta e desencadeia a epifania: "O que chamava de crise viera afinal" (p. 23) e percebe uma realidade voluntária autônoma coexistindo simultânea ao seu modo controlado de viver.

Em $O$ crime do professor de Matemática, um senhor de meia-idade, professor de matemática, encontra-se assolado pela culpa de ter abandonado o cachorro da família, José. Em uma tentativa de punir-se ou simplesmente pagar um tributo ao cão desamparado, o homem decide enterrar um outro cão morto que encontrou numa esquina. Após o ato de "bondade" do funeral, o narrador, em terceira pessoa, nos apresenta a consciência do professor bem como os motivos e razões que o fizeram abandonar aquele cão. Como se tomasse a consciência que seu crime jamais seria punido, o protagonista acaba por desfazer seu ato de piedade ao cão morto, pois matematicamente a existência voluntária de José não pode ser substituída.

Embora não haja um momento que se possa chamar propriamente epifânico neste último conto, ambos os textos revelam reflexões de persona-

\footnotetext{
${ }^{1}$ Como haverá diversas citações deste livro no decorrer do texto, optamos em apenas citar a página em que a citação se encontra, sabendo que todas fazem parte da mesma referência - LISPECTOR, 1983.
} 
gens que são confrontadas por aspectos da vida que escapam ao controle da racionalidade e da rotina (Ana através de sua vida controlada de mãe e mulher e o professor através da lógica matemática). Ambos são desafiados por algo (um cego e um cão) que foge ao esforço que cada um empreende em nome de uma ordem em sua vida.

\section{O processo de formação e fragmentação da identidade}

De acordo com Stuart Hall (2006, p. 8), as identidades na modernidade estão sendo descentradas, ou seja, deslocadas e fragmentadas. Entre as diversas possíveis razões que sustentam esse processo está o fato de as sociedades modernas, a partir do século XX, assumirem nova forma de organização estrutural, fragmentando assim as paisagens culturais de classe, gênero, sexualidade, etnia, raça e nacionalidade, que no passado forneciam sólidas localizações aos indivíduos.

Segundo Hall, são essas transformações sociais as principais responsáveis pela mudança nas identidades pessoais, abalando a ideia da existência de um sujeito centrado e gerando assim a chamada "crise de identidade" (idem, p. 9). Sérgio Paulo Rouanet (1993, p. 9) defende que o que está em crise também é o projeto civilizatório, pois atrás da crise da modernidade, que acarreta diversas consequências nos indivíduos, está a falência do projeto de civilização, este que deveria se pautar em alguns critérios norteadores que agora estão em colapso. Nesse contexto, as identidades sociais entram em crise. Mas antes de nos atermos a esse processo de fragmentação é necessário refletir como os sujeitos se individualizam.

Se pensarmos identidade sob uma perspectiva dialógica veremos que o que se entende por sujeito é uma construção feita pelo outro. O russo Mikhail Bakhtin (2003, p. 13) afirma que "avaliamos a nós mesmos do ponto de vista dos outros, através do outro procuramos compreender e levar em conta os momentos transgredientes à nossa própria consciência". Ou seja, com base nesse viés, o outro interfere diretamente no processo de formação identitária do sujeito, na medida em que um "sentido de si” é construído na negociação com o olhar alheio.

Sinteticamente, esse viés sustenta o conceito de exotopia de Bakhtin, já que é a visão externa a única capaz de fornecer as informações que nos 
permitem definir como sujeitos. Exotopia é o excedente de visão do outro, é o desdobramento das múltiplas opiniões exteriores sobre nós.

Nos contos aqui considerados, a figura do outro é de extrema importância no processo de tomada de consciência das personagens principais. Em Amor, Ana é influenciada pelo cego e em $O$ crime do professor de Matemática, é um cachorro o responsável pelo abalo da identidade do protagonista.

\section{O descentramento e a tomada de consciência}

No conto Amor, a personagem central é descrita pelo narrador em terceira pessoa, como alguém que, "no fundo, sempre tivera necessidade de sentir a raiz firme das coisas" (p. 20). Para a Ana, "a vida podia ser feita pela mão do homem" (p. 20) e como uma lavradora ela plantara sementes a fim de cultivar sua vida. Todos os dias ela tomava a mesma rotina de cuidar da casa e da família.

Porém, havia uma hora perigosa na tarde, uma hora em que ninguém mais precisava dela, momento este quem que "as árvores que plantara riam dela" (p. 20):

Olhando os móveis limpos, seu coração se apertava um pouco em espanto. (...) Saía então para fazer compras ou levar objetos para consertar, cuidando do lar e da família à revelia deles. Quando voltasse era o fim da tarde e as crianças vindas do colégio exigiam-na. Assim chegaria a noite, com sua tranqüila vibração. De manhã acordaria aureolada pelos calmos deveres. Encontrava os móveis de novo empoeirados e sujos, como se voltassem arrependidos. Quanto a ela mesma, fazia obscuramente parte das raízes negras e suaves do mundo. E alimentava anonimamente a vida. Estava bom assim. Assim ela o quisera e escolhera. (p. 21).

Ana precisa do outro para se manter estabilizada em suas raízes: o marido, os filhos, a casa, a costura, as coisas para consertar e comprar, tudo isso representa o externo necessário para mantê-la devidamente "encaixada" em seu "destino de mulher", pois "assim ela o quisera e o escolhera". (p. 20, 21).

O narrador aponta que em função da necessidade de sentir as coisas em seus devidos lugares, de buscar uma estabilidade para a vida, Ana "um lar perplexamente lhe dera" (p. 20) e sua vida anterior à constituição da família 
estava para sempre fora de seu alcance. Criara em troca uma vida de adulto, a qual estava devidamente estruturada sobre sua casa e sua família.

Ana claramente criou sua vida de adulta, porque, segundo Terry Eagleton (apud PERRONE-MOISÉS, 2007, p. 16), pior que ter uma identidade é não ter uma. "O paradoxo da política de identidade, em resumo, é que se precisa de uma identidade a fim de se sentir livre para desfazer-se dela". Ana tricotara uma forma de viver dentro dos moldes sociais, quisera ter uma família para cuidar e se protegera no regaço de uma casa.

Gaston Bachelard (2003, p. 26) afirma que sem a casa o homem seria um ser disperso, já que esta o mantém protegido das tempestades do céu e das tempestades da vida. A casa é um ambiente controlado, fechado, um abrigo estável regido por leis de centralização. Ana busca esse ambiente para que possa se sentir segura, como se sua imaginação construísse paredes com sombras impalpáveis e ela pudesse se reconfortar com a ilusão de proteção (idem, p. 25).

Porém, como afirma Stuart Hall (2006, p. 25), "as transformações associadas à modernidade libertaram o indivíduo de seus apoios sustentáveis nas tradições e nas estruturas". Certo dia voltando das compras rotineiras, Ana tomou um bonde "com as compras deformando o novo saco de tricô" (p. 19) e foi então que teve o contato com o insólito. Em uma das paradas do bonde a protagonista viu um homem parado no ponto. Era um cego. "O que havia mais que fizesse Ana se aprumar em desconfiança? Alguma coisa intranqüila estava sucedendo. Então ela viu: o cego mascava chicles... Um homem cego mascava chicles" (p. 22).

Ana ainda teve tempo de pensar por um segundo que os irmãos viriam jantar - o coração batia-lhe violento, espaçado. Inclinada, olhava o cego profundamente, como se olha o que não nos vê. Ele mascava goma na escuridão. Sem sofrimento, com os olhos abertos. O movimento da mastigação fazia-o parecer sorrir e de repente deixar de sorrir, sorrir e deixar de sorrir - como se ele a tivesse insultado, Ana olhava-o. E quem a visse teria a impressão de uma mulher com ódio. Mas continuava a olhá-lo, cada vez mais inclinada - o bonde deu uma arrancada súbita jogando-a desprevenida para trás, o pesado saco de tricô despencou-se do colo, ruiu no chão (p. 22).

Neste momento pode-se observar a ocorrência da chamada epifania, que, de acordo com Affonso Romano de Sant'Anna (apud MORAES 2008, p. 2), é o "relato de uma experiência que a princípio se mostra simples e rotineira, 
mas que acaba por mostrar toda a força de uma inusitada revelação". É um momento em que o banal torna-se extraordinário levando o sujeito envolvido à tomada de consciência. A epifania, então, acontece quando "fenômenos estatisticamente insignificantes podem mostrar ser decisivos" (BAUMAN, apud FABRÍCIO; LOPES, p. 13).

Há uma simbologia muito forte neste conto. Ana, que sempre buscara uma vida estabilizada, tangível e controlada, carrega, dentro de um bonde, um

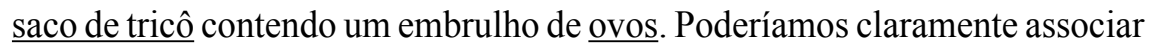
os ovos e a rede de tricô à vida contida de Ana, já que a casca tem uma função de reter, selar a viscosidade (que pode ser associada à subjetividade) do seu interior fazendo do ovo algo palpável, uno, integrado, compreensível (objetivo); a bolsa de tricô, por sua vez, tem a mesma função de controle, segurando, unificando, retendo aquilo que poderia estar disperso, sem forma, misturado ao escuro das "raízes negras e suaves do mundo" (p. 20).

Ao perplexamente criar um lar para si, Ana busca selar toda sua viscidez incompreensível e criar "em troca algo enfim compreensível, uma vida de adulto" (p. 21), pois ela "parecia ter descoberto que tudo era passível de aperfeiçoamento, a cada coisa se apresentaria uma aparência harmoniosa" ( $p$. 20). Os ovos representam esse movimento de retenção da sua vida. O que era mole e voluntário ganhara uma forma estanque.

Quando acontece o momento de epifania, Ana deixa cair a bolsa com os ovos no chão fazendo com que a casca se rompa e gemas amarelas e viscosas escorram entre os fios da rede: "o mal estava feito" (p. 23). "A rede de tricô era áspera entre os dedos, não íntima como quando a tricotara. A rede perdera o sentido e estar num bonde era um fio partido; não sabia o que fazer com as compras no colo" (p. 23). A vida que criara (tricotara) pra si agora lhe era estranha, pois se misturara com o resto do mundo, com tudo aquilo que não era Ana.

O bonde pode ser visto como um índice de instabilidade que se opõe à casa. Diferentemente do ambiente doméstico, estável, estático, o bonde era algo em movimento, que não se podia controlar, movimento da vida: "começou a andar" (p. 19); "vacilava nos trilhos"; "se arrastava"; "estacava" (p. 21); "deu uma arrancada súbita” (p. 22); "se sacudia nos trilhos" (p. 23). Após o momento epifânico a vida perdera a lei que a regia, como se o bonde saísse dos trilhos e estivesse num fio partido. Ana que vivia em passividade é sacudida pelos movimentos do bonde. 
Expulsa de seus próprios dias, parecia-lhe que as pessoas da rua eram periclitantes, que se mantinham por um mínimo equilíbrio à tona da escuridão - e por um momento a falta de sentido deixava-as tão livres que elas não sabiam para onde ir. Perceber uma ausência de lei foi tão súbito que Ana se agarrou ao banco da frente, como se pudesse cair do bonde, como se as coisas pudessem ser revertidas com a mesma calma com que não o eram (p. 23).

A viscosidade das gemas do ovo escorrendo pela rede de tricô pode ser associada à vida que foge ao controle, que rompe a casca da objetividade e que facilmente pode ser moldada a qualquer coisa e não apenas àquilo que era programado para ser: sua vida de mãe, esposa e mulher. É essa ausência de lei que assusta Ana, a selvageria do mundo.

Como a protagonista criara para si uma vida protegida dentro de uma casca de adulta, sua vida anterior parece-lhe estranha como "doença de vida" (p. 20) e dela havia aos poucos emergido. Se ainda pensarmos no ovo como uma metáfora para a vida de Ana, um fato é importante: quando o ovo é posto pela galinha, ainda possui uma casca mole, mas com o contato com o ar torna-se firme.

Ana nem sempre fora alguém controlada, a vida que inventou para si criou sobre ela uma casca, retendo a possibilidade da dispersão. Se "o mundo se tornara de novo um mal-estar" (p. 23, sem grifos no original) é porque um dia já foi desconfortável, "mole". Antes de ter um lar, Ana experimentara "uma exaltação perturbada que tantas vezes se confundira com felicidade suportável” (p. 20).

Por isso "sua precaução reduzia-se a tomar cuidado na hora perigosa da tarde" (p. 21), pois ela bem sabia o que poderia voltar a acontecer. Para ser quem ela gostaria de ser era preciso aceitar essa diária vida periclitante. Todos os dias encontraria as mesmas funções a cumprir e correria os mesmos riscos: isso, na sua concepção, a fazia ser uma mulher adulta. "Ana respirou profundamente e uma grande aceitação deu a seu rosto um ar de mulher” (p. 21)

Segundo Branca Falabella Fabrício e Luiz Paulo da Moita Lopes (2002, p. 14), o contato com o outro possibilitou a desestabilização de sujeitos unificados, gerando neles uma sensação de vertigem, labirinto, como se tirassem o chão debaixo de seus pés. 
A ideia de vertigem em face da questão identitária na contemporaneidade pode ser relacionada ao mundo dos sentidos e sua irredutibilidade à lógica do mesmo, ou seja, daquilo que nos é familiar. A ideia de abismo advém de nossa compreensão teórica sobre a linguagem, não como solo seguro e firme ou estrutura sólida, mas como espaço labiríntico e movente. Tal aspecto de nossas práticas discursivas fica mais latente quando, ao nos confrontarmos com o outro "estrangeiro", não reconhecemos fronteiras familiares de significados onde nos ancorar. (FABRÍCIO; LOPES, 2002, p. 14).

"Vários anos ruíam, as gemas amarelas escorriam" (p. 23). As gemas de Ana se assemelham em flexibilidade ao chiclete do cego, que facilmente se adapta em outras formas. Isso assustou Ana e quem a olhava "teria a impressão de uma mulher com ódio" (p. 22), pois a vida do cego era uma vida voluntária, já que sem sofrimento mascava goma na escuridão e "o movimento da mastigação fazia-o parecer sorrir e de repente deixar de sorrir, sorrir e deixar de sorrir" (p. 22).

Ela apaziguara tão bem a vida, cuidara tanto para que esta não explodisse. Mantinha tudo em serena compreensão, separava uma pessoa das outras, as roupas eram claramente feitas para serem usadas e podia-se escolher pelo jornal o filme da noite - tudo feito de modo a que um dia se seguisse ao outro. E um cego mascando goma despedaçava tudo isso. (p. 24).

Ao contemplar a vida voluntária do cego, Ana vê a sua ruindo, parecia que tudo o que vivera até o encontro com esse outro estava de sobreaviso e tinha um ar mais hostil e perecível. Ela então percebe ao seu redor uma vida espontânea na "Rua Voluntários da Pátria" (p. 24), mas ninguém tinha piedade daquele cego e ela "caíra numa bondade extremamente dolorosa" (p. 24).

O cego mostrava-lhe uma nova maneira de viver, que para Ana era "uma vida cheia de náusea doce, até a boca" (p. 24). Ela olhava as coisas com prazer intenso, sofrendo espantada em um calor que a abafava: "tudo tinha ganho uma força e vozes mais altas" (p. 24).

Ao descer do bonde com pernas débeis, a protagonista encontra-se desnorteada. Como perdera o ponto costumeiro, caminha a esmo, "enquanto a vida que descobrira continuava a pulsar e um vento mais morno e mais misterioso rodeava-lhe o rosto" (p. 24, 25). Até que então reconhece a rua e chega ao Jardim Botânico. 
A descrição desse ambiente é muito importante para se entender o estado interior de Ana, que percebe, talvez pela primeira vez, como a vida daquele parque acontece de forma desordenada, selvagem, mas voluntária.

Ao seu redor havia ruídos serenos, cheiro de árvores, pequenas surpresas entre os cipós. (...) Os ramos se balançavam, as sombras vacilavam no chão. Um pardal ciscava na terra. (p. 25)

Nas árvores as frutas eram pretas, doces como mel. Havia no chão caroços secos cheios de circunvoluções, como pequenos cérebros apodrecidos. O banco estava manchado de sucos roxos. Com suavidade intensa rumorejavam as águas. No tronco da árvore pregavam-se as luxuosas patas de uma aranha. A crueza do mundo era tranquila (p. 26).

A protagonista sente o parque e, de súbito, com mal-estar, percebe que ali começara a acontecer um trabalho secreto, uma emboscada. Ela estava novamente defronte à vida desregrada, espontânea: uma ameaça à sua vida que sempre fora controlada. Mas aquela selvageria, aquela "vastidão parecia acalmá-la, o silêncio regulava sua respiração. Ela adormecia dentro de si" (p. 25), porque "tudo era estranho, suave demais, grande demais" (p. 25). "Era um mundo de se comer com os dentes. (...) Como a repulsa que precedesse uma entrega - era fascinante, a mulher tinha nojo, e era fascinante" (p. 26).

Ana percebe que a vida que levara até então era algo totalmente diferente. Quando pensa que em sua casa existem crianças e homens grandes com fome esperando-a para cumprir sua função de mãe e dona de casa, tem náusea. E dessas pesadas coisas ela lembra com a cabeça rodeada por um enxame de insetos, os quais são enviados pela vida mais fina do mundo.

"A moral do Jardim era outra. Agora que o cego a guiara até ele, estremecia nos primeiros passos de um mundo faiscante, sombrio, onde vitórias-régias boiavam monstruosas" (p. 26). Ana se sente como se estivesse grávida e abandonada, assim como Macabéa de $A$ hora da estrela (LISPECTOR, 1998, $\mathrm{p}$. 79), que se sente grávida de futuro. Ana sente enjoo por perceber a possibilidade de uma nova vida mais livre, como se estivesse também grávida do porvir.

Ana sente o Jardim, experimenta a vida do cego, sente o cheiro adocicado da vida, sob os pés a terra fofa, e aspirava tudo isso com delícia. "O Jardim era tão bonito que ela teve medo do Inferno" (p. 27). Mas essa felicidade, esse amor cru e livre, que talvez pela primeira vez experimentava, era perecível, "o mundo era tão rico que apodrecia" (p. 26). 
E ela não pode viver ali, pois criara para si uma vida de mulher que age em favor de sua família. "Havia lugares pobres e ricos que precisavam dela. Ela precisava deles...” (p. 28) e quando se lembrou das crianças sentiu-se culpada e saiu quase correndo para sua casa e enquanto não chegou ao edifício se sentiu à beira de um desastre.

Abriu a porta de casa. A sala era grande, quadrada, as maçanetas brilhavam limpas, os vidros da janela brilhavam, a lâmpada brilhava — que nova terra era essa? E por um instante a vida sadia que levara até agora pareceu-lhe um modo moralmente louco de viver. O menino que se aproximou correndo era um ser de pernas compridas e rosto igual ao seu, que corria e a abraçava (p. 27).

Ana tem uma sensação de estranhamento ao constatar as diferenças entre a vida que levava e a forma com que existiam o cego e o Jardim Botânico. Na sua casa tudo era limpo, regrado, ela criara para si uma casca para abrigar toda sua viscosidade interior "do mesmo modo como sempre fora fascinada pelas ostras, com aquele vago sentimento de asco que a aproximação da verdade lhe provocava, avisando-a" (p. 27, 28).

Interessante é a descrição do filho: "um ser de pernas compridas e rosto igual ao seu" (p. 28). No Jardim Botânico, Ana experimenta um amor sinestésico, não regrado de moral e tradição, mas de sensações, visões, cheiros; um amor voluntário e não pré-estabelecido pelas relações de parentesco ligadas à família, por isso ela sente estranhamento ao ver aquele ser com o rosto igual ao seu.

“Abraçou o filho, quase a ponto de machucá-lo. Como se soubesse de um mal - o cego ou o belo Jardim Botânico? — agarrava-se a ele, a quem queria acima de tudo" (p. 28). Ela descobrira que amava o filho não simplesmente porque devia amá-lo por ser sua mãe. Mas a vida que sentiu naquele parque, instigada pelo cego, "chamava-a como um lobisomem é chamado pelo luar. Oh! mas ela amava o cego! pensou com os olhos molhados" (p. 29) e com medo apertou o filho: "Não deixe mamãe te esquecer, disse-lhe" (p. 28).

Não havia como fugir. Os dias que ela forjara haviam-se rompido na crosta e a água escapava. Estava diante da ostra. E não havia como não olhá-la. De que tinha vergonha? É que já não era mais piedade, não era só piedade: seu coração se enchera com a pior vontade de viver (p. 28). 
Jonathan Culler (1999, p. 110) afirma que a literatura sempre se preocupou com questões sobre identidade, já que obras literárias caracteristicamente representam indivíduos em suas tensões internas e externas: "A identidade fundamental dos personagens emerge como o resultado de ações, de lutas com o mundo, mas aí essa identidade é postulada como sendo base, até mesmo a causa dessas ações" (idem, p. 109, sem grifos no original).

Ana está em crise de identidade, entre a cultura e natureza, pois não sabia se amava mais o cego e a vida voluntária do Jardim Botânico ou a sua vida de mãe e mulher, que tricotara para si. Se ela vivesse como sempre vivera se sentiria como do lado daqueles que feriram os olhos daquele homem e "com horror descobria que pertencia à parte forte do mundo" (p. 28, 29). $\mathrm{O}$ que deveria fazer para se sentir parte daquela vida espontânea que experimentara e queria para si? "Um cego me levou ao pior de mim mesma, pensou espantada. (...) Humilhada, sabia que o cego preferiria um amor mais pobre. E, estremecendo, também sabia por quê" (p. 29).

Mas a protagonista sabe que se o seguisse iria sozinha, pois a vida que criara para si continuava: "o bonde se sacudia nos trilhos e o cego mascando goma ficara atrás para sempre. (p. 23) (...) O que o cego desencadeara caberia nos seus dias?" (p. 30). O contato com o outro mostrou a Ana que viver é periclitante e que era mais fácil ser um santo que uma pessoa: "a vida arrepiava-a, como um frio" (p. 29).

Mesmo voltando para sua casa e assumindo novamente o destino que escolhera, Ana se sente diferente e consegue perceber agora, simultânea à sua controlada vida doméstica, um rumor espontâneo:

Ouvia o sino da escola, longe e constante. O pequeno horror da poeira ligando em fios a parte inferior do fogão, onde descobriu a pequena aranha. Carregando a jarra para mudar a água - havia o horror da flor se entregando lânguida e asquerosa às suas mãos. $O$ mesmo trabalho secreto se fazia ali na cozinha. Perto da lata de lixo, esmagou com o pé a formiga. O pequeno assassinato da formiga. O mínimo corpo tremia. As gotas d'água caíam na água parada do tanque. Os besouros de verão. $\mathrm{O}$ horror dos besouros inexpressivos. Ao redor havia uma vida silenciosa, lenta, insistente. Horror, horror. Andava de um lado para outro na cozinha, cortando os bifes, mexendo o creme. Em torno da cabeça, em ronda, em torno da luz, os mosquitos de uma noite cálida. Uma noite em que a piedade era tão crua como o amor ruim. Entre os 
dois seios escorria o suor. A fé a quebrantava, o calor do forno ardia nos seus olhos (p. 29, 30. Sem grifos no original).

O cego para sempre a mudara e mesmo que ela tenha voltado a sua vida na casa, usando os ovos para cozer o jantar, eram poucos os ovos agora. Ana percebe que também precisa da família: "Riam-se de tudo, com o coração bom e humano. As crianças cresciam admiravelmente em torno deles. E como a uma borboleta, Ana prendeu o instante entre os dedos antes que ele nunca mais fosse seu" (p. 30).

A protagonista se torna efetivamente um sujeito, pois consegue distinguir agora a fronteira tênue entre dois mundos, duas formas de viver. Sobre isso, Culler (1999, p. 108), afirma que "o sujeito é um ator ou agente, uma subjetividade livre que faz coisas, como no "sujeito de uma sentença". Mas um sujeito também é sujeitado, determinado. (...) A teoria se inclina a argumentar que ser um sujeito também é estar sujeitado a vários regimes" (sem grifos no original).

Ana precisou do outro para perceber a vida coexistindo simultânea à sua vida. Ela percebe então gestos não comuns na atitude do marido, este que até o acontecimento do bonde é descrito como alguém "chegando com os jornais e sorrindo de fome" (p.19), que apenas necessitava da sua função de esposa. Ana entende o amor. "Não quero que lhe aconteça nada, nunca! disse ela" (p. 31).

A tomada de consciência desencadeada pelo cego faz a protagonista se sentir dependente e livre ao mesmo tempo. Ela precisa dos outros para ser quem sonhara ser, mas necessita viver espontaneamente tudo aquilo: "Depois, quando todos foram embora e as crianças já estavam deitadas, ela era uma mulher bruta que olhava pela janela" (p. 30). Ana fora mudada pelo cego e sentiu-se tão crua e viva quanto a vida livre do Jardim Botânico. Ela entendeu o que Goethe (1992, p. 31), como citado na epígrafe deste trabalho, diz: "O mais belo estado de vida é a dependência livre e voluntária: e como seria ela possível sem amor?".

Amor. O nome deste primeiro conto pode nos remeter a $O$ Crime do professor de Matemática, este texto tão marcado também pela inconfortável aparição do outro que demonstra uma forma de viver voluntária, uma forma de amar espontânea. Nesse conto, o protagonista é confrontado por um cachorro e, na sua objetividade de professor de matemática, é agredido pela 
voluntariedade daquele cão verdadeiro e subjetivo que apenas exigia que seu dono fosse verdadeiramente um homem, nada mais.

O professor envolto em culpa decide enterrar então um cão desconhecido em favor de seu crime de ter abandonado José - nome que dera ao cão que deixara em outra cidade. Buscou um lugar muito longe dos olhos e ouvidos de todos. Do alto da colina aquele homem apenas conseguia distinguir os tetos irregulares das casas e a igreja que lá embaixo chamava, com os sinos, "os fiéis para o consolo da punição" (p. 138). Ele também fora chamado a essa atitude penitencial, mas não por uma instituição, e sim por uma lógica própria de si: um débito que tinha com o mundo e deveria quitá-lo de alguma forma.

Escolhera enterrar um cão desconhecido que encontrara morto em uma esquina a fim de redimir-se com José. "Não havia nenhuma confusão na cabeça do homem. Ele se entendia a si próprio com frieza, sem nenhum fio solto" (p. 139).

O professor começa a procurar matematicamente o centro exato da chapada, pois era o lugar onde enterraria se fosse o verdadeiro cão. Devido à dificuldade simétrica de encontrar o centro do lugar, o professor decide fazer a cova no lugar em que ele se encontrava, pois o ato tinha outro objetivo e não exigia pormenores insignificantes como aquele: "Tratava-se de expor um fato, e de não lhe permitir a forma íntima e impune de um pensamento" (p. 139).

Fez o buraco, mas não cavou muito, pois se fosse para o verdadeiro cão cavaria pouco, porque ficando "à superfície da terra não perderia a sensibilidade" (p. 140). Ele pega aquele "cão estranho e objetivo" (p. 140) e o enterra, fazendo com aquele animal se tornasse apenas uma excrescência na superfície do planalto. Deu um sorriso inocente de libertação, pois fizera tudo. Seu crime estava punido e ele agora poderia pensar livremente em José, “o que ele evitara até agora" (p. 140).

Pensar no verdadeiro cão era pensar em sua verdadeira vida. A relação entre o cão e o homem era de uma afinidade dialógica, pois um exprimia coisas sobre o outro:

"Dei-te o nome de José para te dar um nome que te servisse ao mesmo tempo de alma. E tu - como saber jamais que nome me deste? Quanto me amaste mais do que te amei" (...) "Nós nos compreendíamos demais, tu com o nome humano que te dei, eu com o nome que me deste e que nunca pronunciaste senão com o olhar insistente", pensou o homem sorrindo com carinho, livre agora de se lembrar à vontade (p. 141). 
Jacques Lacan (apud CULLER, 1999, p. 112) chama de "estádio do espelho" o fato de o ser humano, a partir de criança, se identificar através do outro. Como se o sujeito se visse inteiro em algo e o seu "eu" fosse sendo constituído pelo reflexo de outrem. O cão é esse espelho para o professor, que tem medo da sua imagem refletida pelo animal: "eu surpreendendo em ti uma nova forma de ter minha alma" (p. 141).

"Mas desde então, já começavas a ser todos os dias um cachorro que se podia abandonar" (p. 141), pois sua presença espontânea incomodava a vida objetiva do professor:

Embora meu, nunca me cedeste nem um pouco de teu passado e de tua natureza. E, inquieto, eu começava a compreender que não exigias de mim que eu cedesse nada da minha para te amar, e isso começava a me importunar. Era no ponto de realidade resistente das duas naturezas que esperavas que nos entendêssemos: Minha ferocidade e a tua não deveriam se trocar por doçura: era isso o que pouco a pouco me ensinavas, e era isto também que estava se tornando pesado. Não me pedindo nada, me pedias demais. De ti mesmo, exigias que fosses um cão. De mim, exigias que eu fosse um homem. E eu, eu disfarçava como podia (p. 142).

Aquele homem tinha medo daquilo que realmente era. Quando o cão fitava-o, irredutível, ele ficava desconcertado, com medo que o animal vislumbrasse o seu rosto verdadeiro e eriçado, atingido, fugisse para sempre. Por isso era "todos os dias um cão que se podia abandonar" (p. 141), pois existia "de um modo tão perfeito que se tornava uma alegria insuportável", possuía um "amor inteiramente dado e certo perigo de ódio como se fosse eu quem, pela amizade, te houvesse revelado" (p. 143).

Mas essa revelação acontecia inversamente: era o professor quem vislumbrava seu verdadeiro $e u$ através de José. Isso o atemorizava e ele fremia de horror. O protagonista percebe que não foi ele quem tivera um cão, mas José quem tivera um homem: tivera alguém tão poderoso que, aliviado, decidiu abandoná-lo: "Com alívio abandonou-te. Com alívio sim, pois exigias - com a incompreensão serena e simples de quem é um cão heróico - que eu fosse um homem. Abandonou-te com uma desculpa que todos em casa aprovaram" (p. 143).

Entre os diversos pretextos seus expressos pelas opiniões da sogra e da esposa, aquele homem abandona o cão, pois este era a possibilidade constante 
de pecar, o que, no disfarçado de seus olhos, já era pecado. Então pecou logo para ser logo culpado e este crime substitui o crime maior que ele não teria coragem de cometer. O cão com sua existência voluntária e vinculada a uma selvageria da qual o homem quer escapar é uma ameaça, estar com o cão é enxergar isso que existe no cão e é reflexo do homem.

Só que isso não é o humano da cultura, objetivo, racional. O crime é trair esse algo, esse "núcleo de vida", essa selvageria que, no limite, é o ovo escorrendo da casca, a rede que se desfaz e torna tudo o que existe o interior viscoso e disforme da ostra. Abandonar o cão é trair a si mesmo, pois o homem é o cão, assim como Ana é o cego e o escuro das raízes do mundo.

Se assumirmos José como um espelho para o professor, seria necessário que o protagonista assumisse um amor recíproco, verdadeiro e voluntário como o de José: uma vida espontânea. Por isso o animal é abandonado, caso contrário aconteceria a morte da vida objetiva que levara até então. Assim como Ana que percebe que o assassinato seria profundo (p. 26), o professor de matemática prevê a crise. A diferença das duas personagens é que Ana se deixa envolver pelo outro a ponto de matar em si suas convicções anteriores. O professor mata a existência do cão, antes que ela desencadeasse o conflito.

"Há tantas formas de ser culpado e de perder-se para sempre e de se trair e de não se enfrentar. Eu escolhi a de ferir um cão" (p. 144). Aquele professor sabia que seu crime era insignificante perante todos e que isso fazia do ocorrido algo ainda mais grave, pois "ainda não haviam inventado castigo para os grandes crimes disfarçados e para as profundas traições" (p. 144). Com sua cabeça matemática fria e inteligente, o professor percebe que seu crime era inimputável.

A piedade que sentira pelo cão era a mesma que sentira Ana pelo cego. Ninguém mais se importava com essas situações, exceto esses sujeitos em processo de descentramento e em crise. A consciência de uma vida que se abandona acarreta uma consequência de desestabilização e reflexão no professor:

Mas como se José, o cão abandonado, exigisse dele muito mais que a mentira: como se exigisse que ele, num último arranco, fosse um homem - e como homem assumisse o seu crime - ele olhava a cova onde enterrara a sua fraqueza e a sua condição (p. 145). 
E como se enfim tomasse uma nova consciência sobre tudo, desenterra aquele cão estranho e objetivo, pois "mais matemático ainda, procurava um meio de não se ter punido. Ele não devia ser consolado" (p. 145).

Ao contrário do começo do conto, agora, olhando para os lados, o professor precisa de uma testemunha para o que acabara de fazer: ele finalmente aprendera o que José tanto lhe quisera ensinar. Agora, sim, poderia voltar para o seio da sua família, mais verdadeiro.

Os olhos são elemento importante nos processos de identificação, e posterior perdição, vividos pelas personagens em ambos os conto. Em Amor, o cego, obviamente, é desprovido da visão que toma o mundo seja ele qual for, regrado ou espontâneo. O cego apenas sente o que está ao seu redor, não pensa visualmente, mas sinestesicamente. É essa a vida que Ana almeja para si: uma existência sem valores visuais, aparentes, mas algo verdadeiro e voluntário que se manifeste através de outros sentidos.

Em O crime do professor de matemática, o protagonista precisa muitas vezes retirar os óculos para poder pensar e respirar livremente, como se o objeto que deveria ser de auxílio fosse, antagonicamente, um estorvo. "Tirou os óculos talvez para respirar melhor porque, com os óculos na mão, respirou muito fundo" (p. 137). Como uma baleia que vai à superfície para respirar, o homem diversas vezes precisa retirar os óculos, respirar e voltar a colocá-los.

Quando ele senta para pensar ou olhar a realidade ao seu redor, as casas, o rio, o planalto, a montanha, as escarpas, etc., ele está usando óculos, como se para vislumbrar o mundo fosse preciso uma película protetora para que a vida voluntária que rugia ao seu redor não o contaminasse com sua violência. Por ser míope ele tem dificuldade de ver além, via nitidamente apenas aquilo que estava ao seu alcance, objetivamente só vislumbrava o tangível.

O professor precisa pôr os óculos para agir racionalmente e enterrar o cão. Porém quando puxa o animal morto de dentro do saco ele tem os olhos profundamente fechados, pois nesse momento estava sem óculos e corria um risco de ser atingido pela súbita aparição daquele defunto que representava José.

Ana, por sua vez, ao ter tomado consciência do rumor de vida que ao seu redor se levantava (a vida voluntária) quer comer com os olhos todas as coisas. A descrição detalhada da vida crua e suja do Jardim Botânico em oposição às minúcias da limpeza do seu lar demonstra como a protagonista percebe o mundo através dos seus olhos. 
Por isso tinha piedade e inveja do cego, que vivia em escura sofreguidão. Inveja da comunhão do cego com a selvageria do mundo; piedade também, pois a aliança do cego com o mundo em estado bruto impede qualquer possibilidade de integração.

\section{Considerações finais}

Em geral, a narrativa da escritora Clarice Lispector apresenta uma visão de mundo calcada em uma subjetividade radical. Geralmente suas personagens são visitadas pelo insólito e sentidos novos para suas vidas são criados a partir de momentos reveladores. Ana e o professor de matemática são exemplos de como o processo de tomada de consciência acontece nos sujeitos, sendo crucial em sua formação identitária. Essa tomada de consciência, no entanto, não é simples, envolve a percepção da existência como algo intimamente ligado à noção de vida biológica, matéria viva que pulsa, não redutível à racionalidade histórica e social.

Segundo Culler (1999, p. 109), as obras literárias oferecem um número grande de modelos implícitos de como se forma a identidade. Este trabalho se preocupou em demonstrar como as identidades dos protagonistas dos contos Amor e $O$ crime do professor de matemática são formadas e como, em determinado momento, também são fragmentadas, devido a uma tomada de consciência sobre a vida.

Em geral, a literatura, expressa tradicionalmente por poemas e romances, se dirige aos leitores de maneira a exigir identificação, e a identificação funciona para criar a identidade, pois "nos tornamos quem somos nos identificando com as figuras sobre as quais lemos" (CULLER, 1999, p. 111). Isso reitera o que Bakhtin afirma sobre a função do outro em nossa identidade, já que possuo um excedente de visão sobre outrem e vice-versa capaz de revelar sentidos insólitos através dessa relação dialógica dos sujeitos (BAKHTIN, 2003, p. 21).

Nos contos aqui considerados o outro tem grande importância no processo de construção identitária, descentramento a tomada de consciência dos sujeitos, já que "construímos a outridade ao mesmo tempo em que ela nos constrói” (FABRÍCIO; LOPES, 2002, p. 16). Ana e o professor são sujeitos em crise de identidade, pois estão em fase de autoconhecimento e redefinição. Porém, sabe-se que "a identidade plenamente unificada, completa, segura e 
coerente é uma fantasia" (HALL, 2006, p. 13). Assim, o processo por que passam os protagonistas dos contos revelam um eterno ciclo de amadurecimento do homem situado na pós-modernidade.

Nos contos lidos, a radicalização do sentido do outro se revela fundamental para a compreensão da mudança vivida pelas personagens: a premissa de que tudo que está fora de mim não sou eu é confrontada com o difícil aprendizado de Ana e do professor de matemática de que tudo o que está fora de mim - o outro - sou eu. Eu fora da casca do ovo e da rede tecida pelas mãos da cultura.

\section{Referências}

BACHELARD, G. A poética do espaço. [Trad. Antonio de Pádua Danesi]. São Paulo: Martins Fontes, 1993.

BAKHTIN, M. Estética da criação verbal. [Trad. Paulo Bezerra]. 4 ed. São Paulo: Martins Fontes, 2003.

Questões de literatura e estética: a teoria do romance. [Trad. Aurora Bernardini e outros]. São Paulo: Ed. UNESP, 1998.

CULLER, J. Teoria literária. [Trad. Sandra Vasconcelos]. São Paulo: Beca Produções, 1999.

GOETHE, J. W. Máximas e reflexões. Lisboa: Guimarães Editores, 1992.

HALL, S. A identidade cultural da pós-modernidade. [Trad. Tomaz Tadeu da Silva e Guacira Lopes Louro]. 10 ed. Rio de Janeiro: DP\&A, 2006.

LISPECTOR, C. A hora da estrela. Rio de Janeiro: Rocco, 1998.

Laços de família: contos. 12 ed. Rio de Janeiro: Nova Fronteira, 1983.

FABRÍCIO, B. F.; LOPES, L. P. M. Discursos e vertigens: identidades em xeque em narrativas contemporâneas. Revista Veredas. Juiz de Fora, v. 6, n. 2, jul./dez. 2002. Disponível em: < http://www.ufjf.br/revistaveredas/files/2009/12/cap012.pdf>. Acesso em 10 jun. 2010.

MORAES, R. M. A. Epifania e "crise": uma análise comparativa em obras de Clarice Lispector e Marguerite Duras. Revista Odisseia. Natal, n. 2, dez. 2008. Disponível em: $<$ http:// www.cchla.ufrn.br/odisseia/numero2/arquivos/1_Rozania_Maria_Alves_de_Morais.pdf $>$. Acesso em 22 jul. 2010.

PERRONE-MOISÉS, L. Vira e mexe, nacionalismo. São Paulo: Cia das Letras, 2007.

ROUANET, S. P. Mal-estar na modernidade. São Paulo: Cia das Letras, 1993.

Recebido para publicação em 08 nov. 2010.

Aceito para publicação em 30 mar. 2011. 